\title{
Influensavaksinering av helsepersonell - et moralsk anliggende?
}

\author{
Influensa tar årlig livet av rundt 800 nordmenn. Siden sykdommen lar seg diagnostisere med høy grad av \\ presisjon og dessuten kan forebygges ved vaksinering, burde det være mulig å redusere sykeligheten og \\ dødeligheten ved effektive tiltak. Et sentralt spørsmål i så måte er hva som kan anses som effektive tiltak \\ og - mer spesifikt - i hvor stor grad vaksinering av helsepersonell skal gjelde som ett av disse tiltakene.
}

Helsepersonell har høyt jobbnærvær - $76 \%$ av norske leger angir at de går på jobb selv om de er syke (1). Legges amerikanske studier til grunn (2), er det rimelig å anta at dette også gjelder ved smittsom influensa. I så måte utvises høy arbeidsmoral, men lav behandlermoral. Det moralske dilemmaet jobbnærværet avstedkommer har vært søkt løst ved å anbefale eller endatil pålegge personellet å la seg vaksinere mot influensa. For gjennom en slik handling, hevdes det, kan de bli værende på jobb uten å smitte pasientene.

Dersom begrunnelsen er korrekt, vil selvsagt alt være vel. Men er den feil, kan vaksinering gi falsk trygghet og dermed lavere pasientsikkerhet. I så måte er det utilfredsstillende at det i undersøkelsene der man har søkt å avklare dilemmaet er til dels motstridende resultater.

\section{Ubesvarte spørsmål}

At influensavaksinen beskytter mellom $50 \%$ og $80 \%$ av de vaksinerte synes uomtvistelig (3). Likevel har effekter av vaksinering vært vanskelig å gjenfinne på aggregert nivå. Talende i så måte er en studie fra et amerikansk universitetssykehus der personalet ble pålagt å la seg vaksinere. Nærmere $100 \%$ ble vaksinert, men i løpet av fem influensasesonger viste tiltaket knapt resultater på sykefraværsstatistikken (4).

Uheldigvis ble det ikke undersøkt om vaksineringen hadde effekt på pasientenes sykelighet. Derfor kunne ikke studien gi svar på hvorvidt pasientene fikk gevinst av det omfattende og kostbare tiltaket eller ikke.

Fortsatt finnes det ingen omfattende studier på om pasienter i akuttsykehus får effekt i form av mindre sykdom og død dersom hele eller deler av personalet lar seg vaksinere. Enkelte forfattere har søkt å omgå problemet ved å hevde at studier i akuttsykehus vanskelig lar seg gjennomføre, og dessuten at slike heller ikke trengs fordi sykehjemsstudier viser den ønskede effekt (5). Men troverdigheten til begge disse argumentene er diskutabel. For det første burde det la seg gjøre å undersøke effekt ved for eksempel å sammenlikne akuttsykehus med og uten pålagt vaksinering, for det andre er sykehjemsstudiene beheftet med en rekke svakheter som gjør det uklart om det var vaksineringen eller andre tiltak som ga redusert sykelighet (6).

Inntil bedre studier foreligger er det rimelig å innta en avventende holdning til vaksineringens betydning for pasientsikkerheten. Holdningen kan dels begrunnes ved henvisning til akuttsykehusets kompleksitet hva angår smitteveier, dels ved forhold knyttet til selve vaksineringen.

En relativt høy andel av personalet forblir ubeskyttet etter vaksinering, og selv de som oppnår effektiv beskyttelse, kan skille ut replikasjonsdyktig virus og dermed smitte

\section{«Helsepersonell har en moralsk plikt til å hindre at pasienter innlagt i helseinstitu- sjoner blir smittet av influensa»}

pasientene (7). $\AA$ anta at vaksinert personale er tryggere enn uvaksinert $\mathrm{i}$ behandlingssituasjoner, er således vågalt. I tilfeller der pasientsmitte er spesielt viktig å unngå, bør daglig virustesting av personalet vurderes.

\section{En moralsk avklaring}

Helsepersonell har en moralsk plikt til å hindre at pasienter innlagt i helseinstitusjoner blir smittet av influensa. Men av dette følger ikke at de har en moralsk plikt til å la seg vaksinere, slik amerikanske forskere i økende grad har tatt til orde for $(2,4$, 5). Å oppfordre helsepersonell til å la seg vaksinere av egeninteresse vil derimot kunne være et godt, om enn kortsiktig råd.

Virusets stadige endring nødvendiggjør årlig påfyll av vaksine, noe som i sin tur kan hindre utvikling av et kryssreagerende immunsvar overfor nye influensatyper (8). Slik kan helsepersonell gjøres mindre motstandsdyktig ved utbrudd av en ny pandemi. På lengre sikt kan årlig totalvaksinering av ansatte således falle uheldig ut for personalet og dermed også for pasientene.
Synspunktene i artikkelen er forfatterens egne og representerer ikke nødvendigvis synet til Haukeland universitetssykehus eller Universitetet i Bergen.

\section{Elling Ulvestad}

elling.ulvestad@helse-bergen.no

Elling Ulvestad (f. 1958) er dr.med. og spesialist i immunologi og transfusjonsmedisin. Han er avdelingssjef ved Mikrobiologisk avdeling, Haukeland universitetssykehus, og professor ved Klinisk institutt 2, Universitetet i Bergen. Forfatter har fylt ut ICMJE-skjemaet og oppgir ingen interessekonflikter.

Litteratur

1. Gustafsson Sendén M, Løvseth LT, Schenck-Gustafsson $\mathrm{K}$ et al. What makes physicians go to work while sick: a comparative study of sickness presenteeism in four European countries (HOUPE). Swiss Med Wkly 2013; 143: w13840.

2. Poland GA, Tosh P, Jacobson RM. Requiring influenza vaccination for health care workers: seven truths we must accept. Vaccine 2005; 23: 2251-5.

3. Nichol KL. The efficacy, effectiveness and costeffectiveness of inactivated influenza virus vaccines. Vaccine 2003; 21: 1769-75.

4. Rakita RM, Hagar BA, Crome P et al. Mandatory influenza vaccination of healthcare workers: a 5-year study. Infect Control Hosp Epidemiol 2010; 31: 881-8.

5. Talbot TR, Babcock H, Caplan AL et al. Revised SHEA position paper: influenza vaccination of healthcare personnel. Infect Control Hosp Epidemiol 2010; 31: 987-95.

6. Thomas RE, Jefferson T, Lasserson TJ. Influenza vaccination for healthcare workers who care for people aged 60 or older living in long-term care institutions. Cochrane Database Syst Rev 2013; 7: CD005187.

7. Couch RB, Douglas RG Jr, Fedson DS et al. Correlated studies of a recombinant influenza-virus vaccine. 3. Protection against experimental influenza in man. J Infect Dis 1971; 124: 473-80.

8. Haneberg B, Mamelund SE, Mjaaland S. Influensavaksine - til hvem? Tidsskr Nor Legeforen 2013; 133: $2376-8$.

Mottatt 19.12. 2013, første revisjon innsendt 10.1. 2014, godkjent 20.1. 2014. Redaktør: Kari Tveito.

Publisert først på nett. 